\title{
Analysis of macrobenthic communities in the river basins of Central Italy
}

\author{
L. Mancini ${ }^{1}$, P. Formichetti ${ }^{1}$, J.G. Morgana ${ }^{2}$, L. Tancioni ${ }^{3}$, A.M. D’Angelo ${ }^{1}$, P.P. Danieli ${ }^{4}$, \\ E. Pierdominici ${ }^{1}$, M. Iaconelli ${ }^{1}$ and P. Andreani ${ }^{1}$ \\ ${ }^{1}$ National Institute of Health, V.le Regina Elena 29900161 Rome, Italy; Email: 1mancini@iss.it \\ ${ }^{2}$ ENEA Casaccia, Rome, Italy; \\ ${ }^{3}$ University of Tor Vergata- Rome, Italy; \\ ${ }^{4}$ Gaia p.s.c.r.l., Viterbo, Italy;
}

\begin{abstract}
The macrobenthic communities of many river basins of Central Italy were sampled and analysed with the Extended Biotic Index, modified for Italian rivers (I.B.E.); 101 watercourses of various typologies were sampled and the total number of taxa detected was 130, among which 117 were useful for the determination of the I.B.E. A preliminary analysis was performed in order to determine the correlation between the frequencies of the different Systematic Units (S.U.) and the I.B.E. values. The data were processed in order to develop an index, the Survey Frequency Index (S.F.I.), which computes the presence of a single S.U. at a given I.B.E. score, in relation to the number of sampling sites showing the same score $(I=A y / n B y)$. The presence of a faunal group - Index of Group Presence (I.G.P.) - and of taxon - Index of Taxon Presence (I.T.P.) - was evaluated estimating the average of the mean families and the taxon presence respectively.

The comparison between the autoecology of a given taxon and its relative I.B.E. and Quality Class (Q.C.) index value provides a preliminary interpretation of a reference community structure within a watershed. The analysis of the macrobenthic community has revealed abnormal distributions of some taxa in relation to the water quality in all of the considered river bio-typologies. In particular, some taxa (i.e. Isoperla, Hydropsychidae, Rhyacophilidae and Ephemerella) have showed higher adaptation levels than expected by the I.B.E. scores. This first contribution has underlined the importance of the disposal of basic elements on the autoecology of single indicative taxa for a critical approach on the composition of the reference communities and the ecotypes identification.
\end{abstract}

Keywords: biomonitoring, Italian Extended Biotic Index, Italian river basins, Survey Frequency Index, Index of Group Presence, Index of Taxon Presences.

\section{RESÚMEN}

Las comunidades macrobentónicas de varias cuencas de Italia Central fueron analizadas mediante el método del Índice Biológico Extendido modificado para los rios italianos (I.B.E.). Fueron realizados muestreos en 101 cursos de agua de diferente tipología y el número total de taxones identificados fue 130, de los cuales 117 fueron utilizados para calcular el índice I.B.E. Un análisis fue realizado para determinar la correlación entre las frecuencias de las Unidades Sistemáticas (U.S.) y los valores de I.B.E. Los datos fueron procesados para desarrollar un índice, el Survey Frequency Index (S.F.I.) que considera la presencia de cada U.S. en cada valor de I.B.E. y con relación al número de estaciones de muestreo que presentan la misma puntuación $(I=A y / n B y)$. Las presencias de grupo faunistico -Índice de grupo (I.G.P.)- y de taxón -Índice de Presencia de Taxón (I.T.P.)- han sido evaluadas calculando las presencias medias de las familias y de los taxones respectivamente. La comparación entre la autoecología de cada taxón y los valores de I.B.E. y las respectivas Clases de Calidad ofrece una interpretación preliminar de la estructura de la comunidad de referencia dentro de la cuenca. El análisis de las comunidades macrobentónicas ha mostrado distribuciones anormales de varios taxones con relación a la calidad del agua en todas las bio-tipologías consideradas. En particular, algunos taxones (por ejemplo Isoperla, Hydropsichidae, Rhyacophilidae y Ephemerella) evidencian niveles de adaptación más elevados de lo que se esperaba según los valores obtenidos de I.B.E. Este trabajo demuestra la importancia de utilizar los elementos de autoecología de los taxones para establecer las comunidades de referencia y la identificación de los ecotipos.

Palabras clave: monitoreo biológico, Indice Biótico Extendido Italiano, cuencas italianas, Survey Frequency Index, Índice de Presencia de Grupo, Índice de Presencia de Taxón. 


\section{INTRODUCTION}

Biological monitoring is a tool currently used to characterize running water ecosystems. In particular, the study of river populations and communities of diatoms, macrobenthos, and fishes allows us to build quality indices and maps that are useful in every evaluation of either the degree of "integrity" or the pollution levels, and to obtain direct information about land management (Mostert, 1998; Hellawell, 1978; Karr, 1994).

The basis of this principle is that each river collects the leaching waters and thus the pollutants discharged in the hydrological catchment. Such pollutants can end up being so diluted that it becomes difficult to observe them by simple chemical-physical analyses; meanwhile they affect profoundly the structure and the composition of ecosystems (Vogt et al., 1997). Therefore, environmental modifications highlighted by simple analyses of its biological community reveal habitat modifications (Boon et al., 2000; Karr, 1997; 1999). The analysis of aquatic macroinvertebrates is the most used method for the assessment of the environmental quality. Some taxa result very sensitive to pollutants, resulting as good indicators of water quality, while others are extremely resistant (Wright et al., 1984; 1989).

The biological indices elaborated in the past decades in Europe can be grouped in three main categories: Saprobic Indices, Diversity Indices, and Biotic Indices, combining the indicator value of some taxa with the taxa richness of the community (Tittizer, 1976; Woodwiss, 1980; Ghetti, 1997).

Within the lothic ecosystems, the estimation of the water quality through the Extended Biotic Index (I.B.E.) - (Ghetti, 1997), is an approach that provides useful information on the sensitivity of the various Systematic Units (S.U.) that form the macrobenthos community.

An operator's critical definition of the water quality is important for a correct application of the I.B.E. This consideration is based on the fact that the index is not only a simple reading of a faunal list, but is also based on a series of correctional factors (i.e. the drift, that smooth anomalies such as the passive transport of a given organism). Other factors to take into account are the pollutants' selection capability or "recolonization trends" showed by some aquatic organisms (i.e. Plecoptera and Ephemeroptera), which don't respect the sensitivity scale defined by the I.B.E. This topic introduces the need to develop a sensitivity scale applicable to the single S.U. in order to improve the critical interpretation of the community as well as expressed by the development of the method.

\section{METHODS}

We examined several different rivers of Central Italy, whose data sets had been obtained by standard biological methodologies for evaluation of the water quality (Mancini \& Arcà, 2001).

The Italian National Legislation (Italy, 1999; 2000) considers the I.B.E. (Ghetti, 1986; 1997) as a useful tool to build water quality maps. The I.B.E. is an updated and revised version of the former Extended Biotic Index. Its structure is derived from the Indices elaborated by Woodwiss $(1964,1978)$, later adapted to the Italian environments.

A comparative analysis was therefore performed to estimate the relation between the I.B.E. values and the frequencies of the collected S.U. Despite a poor number of sampling sites with I.B.E. score at the extremes of the range (11-12 and 1.5-2.5 respectively), the comparison allowed to verify the behaviour of each S.U. within the faunal groups.

The data were processed in order to transform simple presence/absence observations (precisely " 1 " and " 0 " values) into frequencies using I.B.E. values as blocking factors. Formally, all sampling stations were grouped according to their I.B.E. (i) values. In this manner, 12 groups were made. In every group, occurrences of single taxon (j) were counted (Tji) and weighted by the number of sampling sites in the group (Ni). We called this frequency the Survey Frequency Index (S.F.I.ji $=\mathrm{Tji} / \mathrm{Ni}$ ), which computes the 


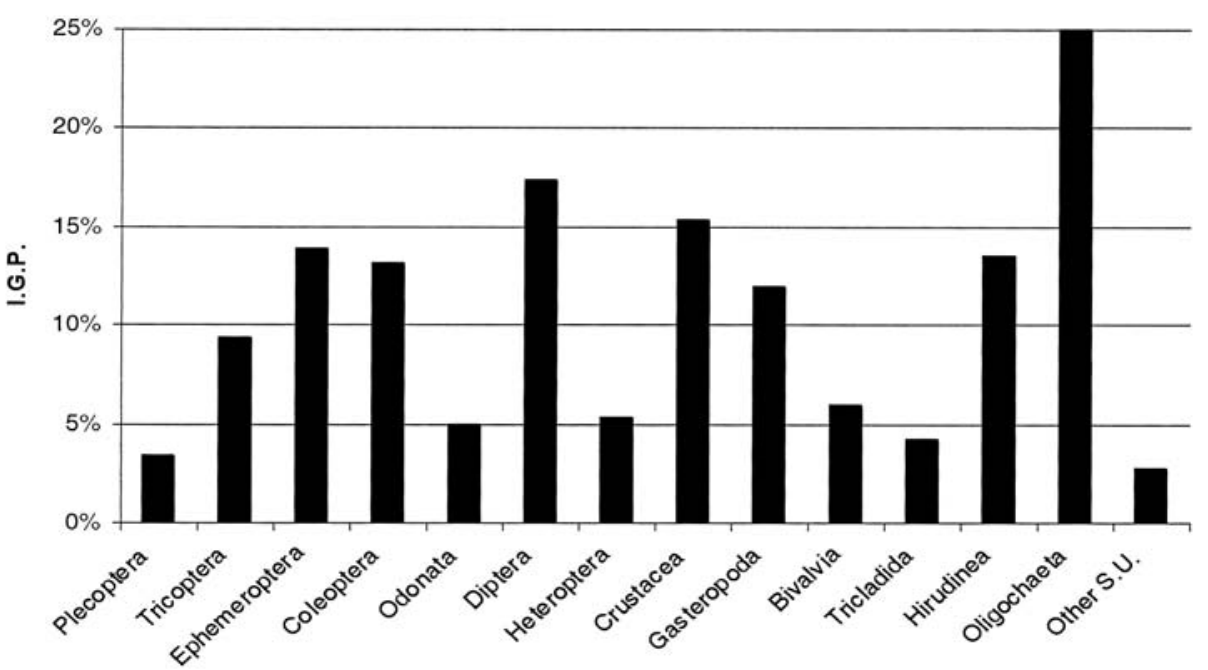

Figure 1: I.G.P. of the different families of macroinvertebrates observed in Central Italy rivers. IGP de las diferentes familias de macroinvertebrados observadas en los ríos de Italia Central.

presence of a single Systematic Unit (S.U.) at a given I.B.E. score. This is a non-dimensional index ranging continuously between 0 and 1 . To compare the values obtained this way with information from entire datasets, the occurrence of a taxon has been evaluated considering the average of its total presence $(\mathrm{Tj})$ on all sampling sites (N) giving an Index of Taxon Presence (I.T.P.). Furthermore, in a similar manner, the presence of a faunal group was evaluated estimating the average of mean families' presence: Index of Group Presence (I.G.P.). Calculations were made using the math-sheet of MS-EXCEL.

\section{RESULTS AND DISCUSSION}

A comparison of IGP of all groups confirms a different distributional pattern within the families. Some groups show a relatively wider distribution compared to others; i.e. Oligochaeta shows sampling frequencies with scores of I.G.P. > 0.24; among the less numerous groups there are several S.U. showing scores $\leq 0.06$ (Fig. 1). The frequency of occurrences observed for the Index of Taxon Presence (I.T.P.) in the different taxa of aquatic macroinvertebrates is showed in Table I.
The analyses of the frequencies in several faunal groups has ruled out marked differences between the families, some of them being always numerically dominant compared to others. This is the case of Plecoptera of the family Leuctridae - especially for Leuctra spp, much more widespread compared to the other S.U. Among Ephemeroptera the most common families are, in decreasing order, Caenidae - especially for Caenis spp., Ephemerellidae - especially for Ephemerella spp. followed by Baetidae - especially for Baetis spp. Other families with higher distribution patterns are Hydropsychidae, Rhyachophilidae and Limnephilidae (Tricoptera); Elmidae (Coleoptera); Calopterygidae followed by Gomphidae and Platycnemidae are the most widespread within the group of Odonata. Chironomidae and Simulidae in the group of Diptera. The groups of Heteroptera, Gasteropoda and Bivalvia show a more or less homogeneous distribution pattern of the relative families. Asellidae and Gammaridae, within Crustacea, are dominant compared to the other families of the group, while Tubificidae and Lumbricidae are the most common among the Oligochaeta as well as the Erpobdellidae in the group of Hirudinea, and Dugesiidae in the group of Tricladida. 
Table 1: Frequency of occurrences observed for Index Taxa Presence (I.T.P.) in the different taxa of aquatic macroinvertebrates. Frecuencia de apariciones observadas del Index Taxa Presence (I.T.P.) en los diferentes taxones de macroinvertebrados acuáticos.

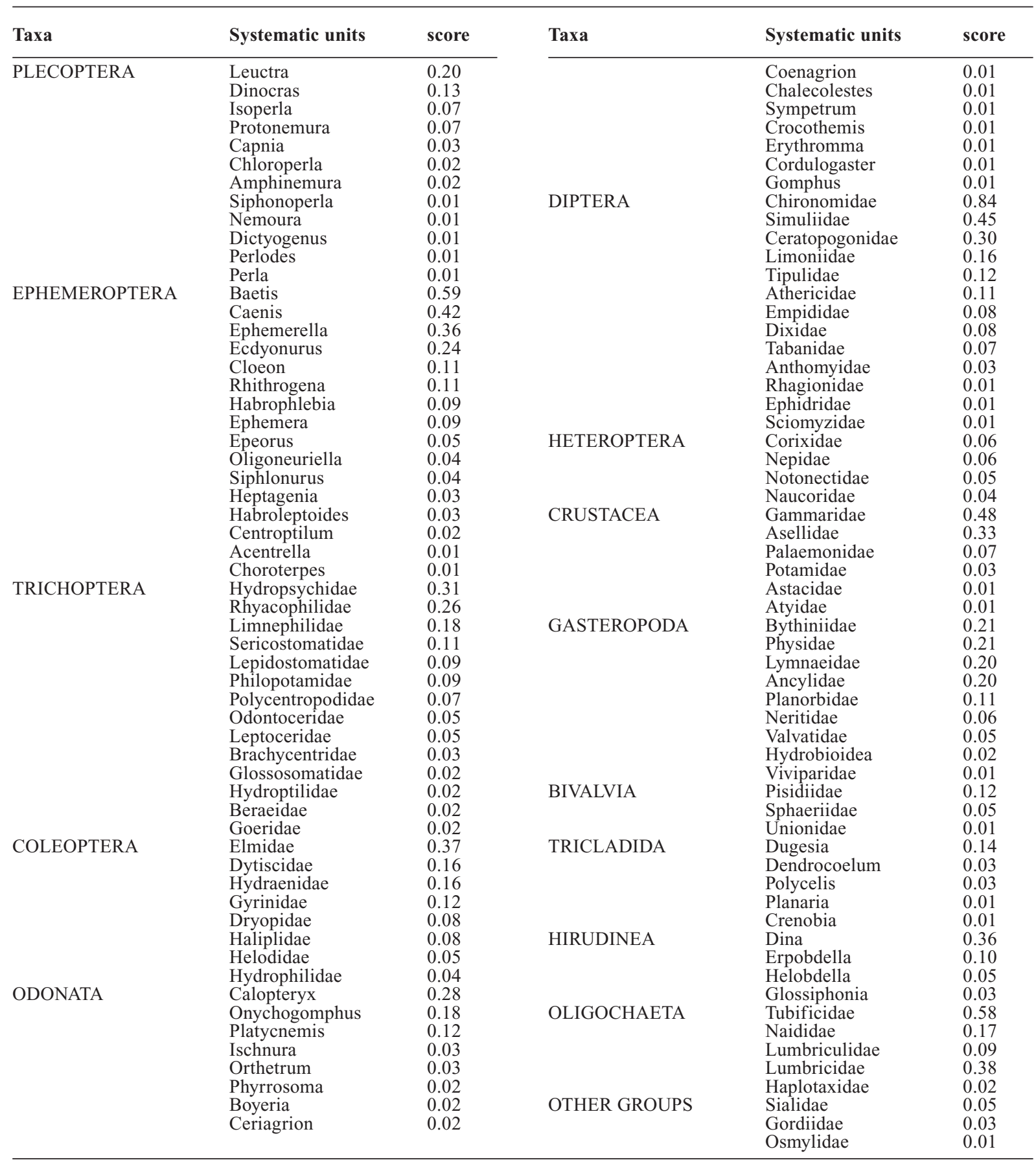

The distribution analysis of the S.U. as described in the I.B.E. has shown marked differences within the groups, i.e. some genera of
Plecoptera, which are generally linked to high quality environments (I.B.E. scores between 12 and 9) can be found in waters with I.B.E. sco- 
res between 9 and 6 (Isoperla, Leuctra and Dinocras). Accordingly, they show a relatively higher sampling frequency compared to the other genera of Plecoptera (mean S.F.I. score 0.2 ), suggesting a direct relation between the sampling frequency and stress resistence (Fig. 2). Tricoptera are mainly distributed at medium-high I.B.E. values showing scores between 12 and 5 (with the exception of Lepidostomatidae sporadically observed at score 4). Most of the S.U. can be observed at 10-8 I.B.E. values. The most widespread families within this group are the Hydrospychiae and the Rhyacophilidae meanwhile the Odontoceridae, the Limnephilidae and the Sericostomatidae are linked to environments of high quality (Fig. 3). Most of the S. U. of the Ephemeroptera show a frequency of distribution between I.B.E. scores 12 and 6. Baetidae and Caenidae as well as Efemerella are the most widespread and can be detected at very low I.B.E. values (Fig. 4) (Alba-Tercedor et al., 1995).

The group Coleoptera shows two different distribution patterns: S.U. which survive at higher I.B.E. scores (between 6 and 12), and those adaptable even at lower scores (between 5 and 2) such as Haliplidae, Gyrinidae, Dytiscidae and Elmidae (Fig. 5). The Odonata are well distributed along the whole range of I.B.E. scale except Chrochotemis (mostly detectable at higher values), and Orthetrum, Ischnura, Onychogomphus observed up to the 5-1 range (Fig. 6). Almost all the S.U. within Diptera are commonly distributed within the Quality Classes I and III, with the exception of Chironomidae and in a lesser amount, Ceratopogonidae. However Athericidae are better distributed at high quality class (Fig. 7). The diagrams of the SFI observed within the family of some group are showed in figures 2 through7.

The group Heteroptera can be observed in a range of I.B.E. scores between 11 and 5 but with a very low survey frequency. The Corixidae appear to be more resistant and are able to colonize waters with 5-4 I.B.E. Among Crustacea the distributions are heterogeneous: there are S.U. with higher degree of tolerance (Asellidae and
Gammaridae), and S.U. correlated to higher scores of water quality (Astacidae and Potamidae), as well as those which increase numerically when the water quality decreases (Paleomonidae). Gasteropoda, detectable in almost all the I.B.E. scores of the index $(11,5-1,5)$, are in average well distributed in a shorter range (11-4). Physidae, Planorbiidae and Ancylidae seem to be better distributed at medium-high I.B.E. values. The Bivalvia are generally linked to high water quality and the family Unionidae is very unfrequent. The distribution pattern of Oligochaeta is quite differentiated and similar to that described for Crustacea. Some S.U. are detectable even at very low quality scores (Tubificidae, Lumbricidae). Lumbriculidae are otherwise generally linked to higher water quality. Within the Hirudinea, Dina is the most widespread genus and its frequency seems to increase with the fall of water quality while the other genera show an increase in their frequency at higher I.B.E. scores. In the group Tricladida most of the S.U. show that they prefer very low pollution levels; only Dugesia appears to be tolerant at relatively lower I.B.E. scores. The other groups, the Osmylidae (Neuroptera) and the Gordiidae (Nematomorpha) are numerically very rare at high I.B.E. scores while the Sialidae (Neuroptera) have a better distribution. The estimation of the numeric distributions in relation to the water quality has ruled out a correlation between abundance and adaptation. That seems to fit in all of the surveyed faunal groups, i.e. the most abundant S.U. are Chironomidae, followed by Tubificidae, Gammaridae, Simulidae, Baetidae, and Caenidae; all of them linked to qualitatively stressed habitats. The abundance scores of S.U. typical of clean waters are always under 0.1 , while the most resistant to polluted environments show higher values (I.G.P 0.4-0.5).

\section{CONCLUSION}

The results of this investigation have ruled out sensitivity variations in comparison to the autoecology, defined by the I.B.E. index, in some of 


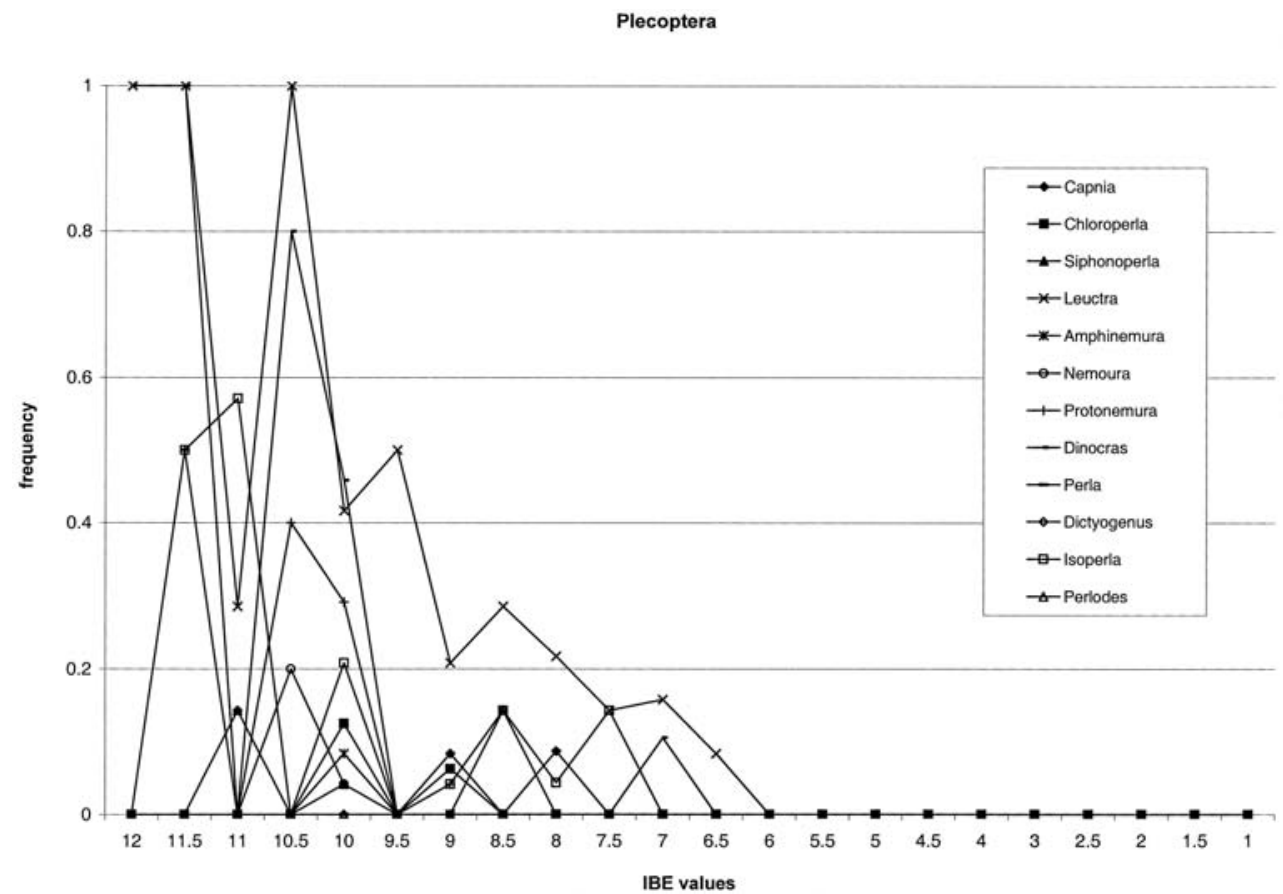

Figure 2: Diagrams of the SFI (Survey Frequency Index) observed in the Order Plecoptera. Diagramas del SFI (Survey Frequency Index) observado en el Orden familia Plecoptera.

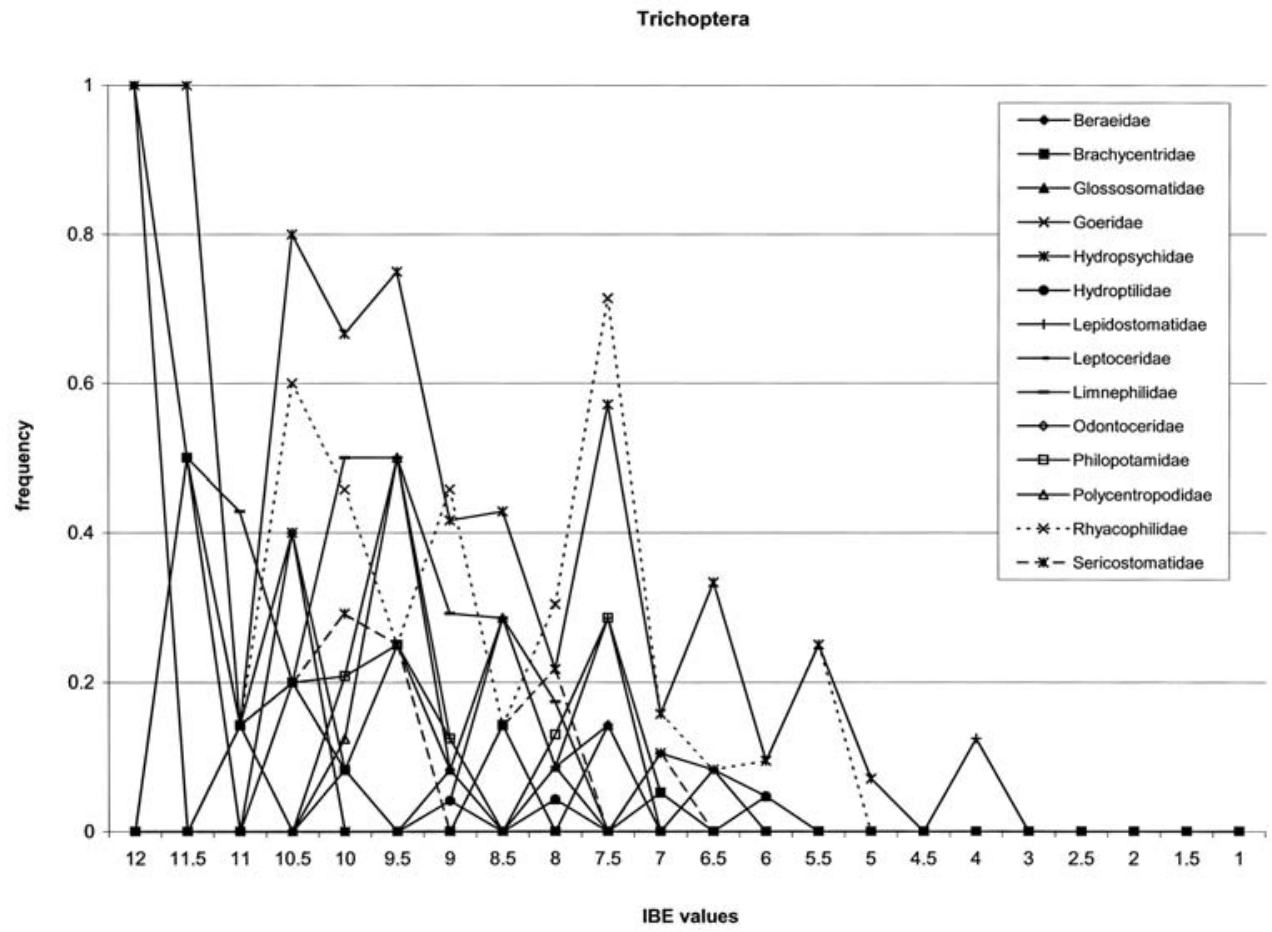

Figure 3: Diagrams of the SFI (Survey Frequency Index) observed in the Order Trichoptera Diagramas del SFI (Survey Frequency Index) observado en el Orden Trichoptera. 


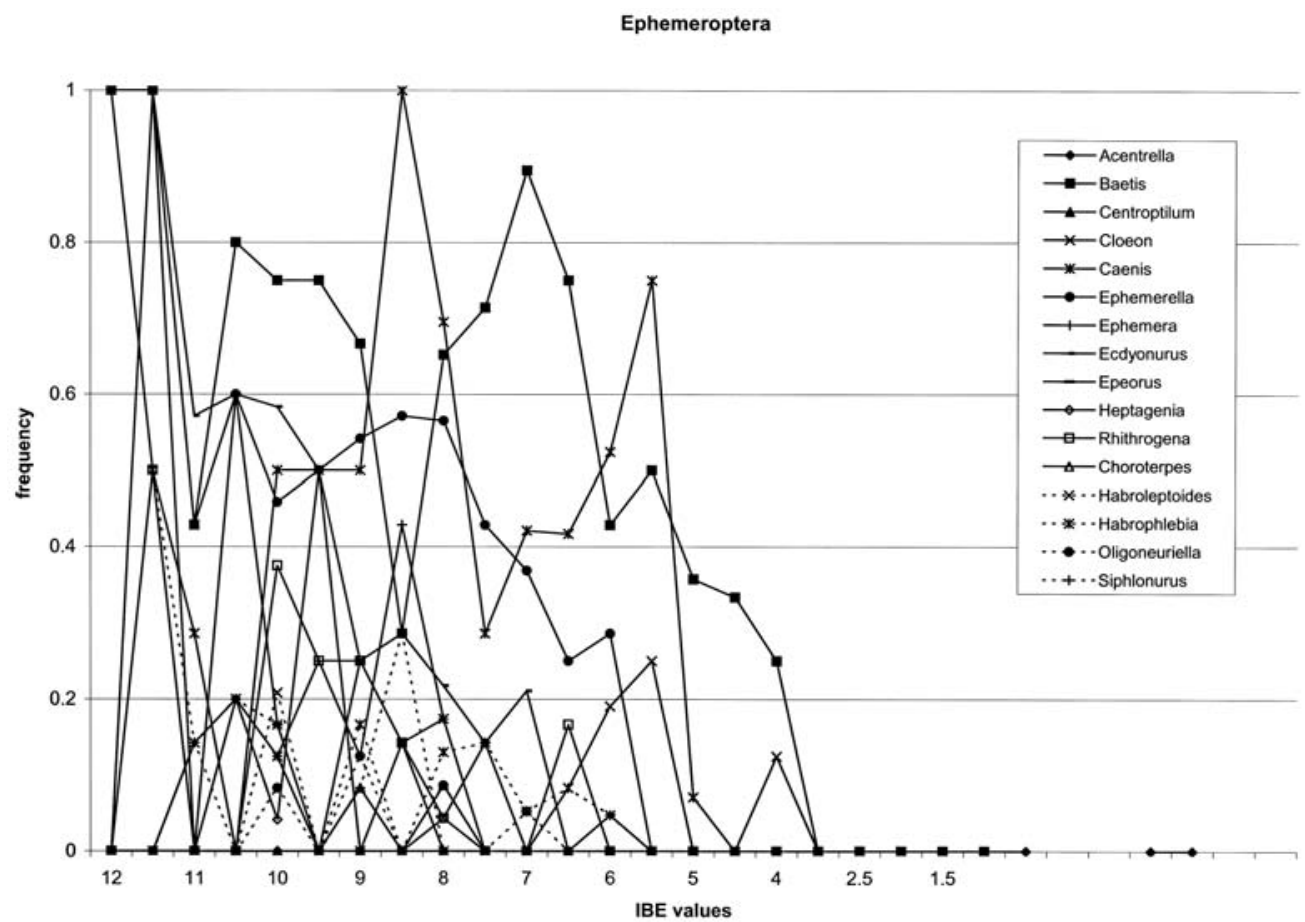

Figure 4: Diagrams of the SFI (Survey Frequency Index) observed in the Order Ephemeroptera. Diagramas del SFI (Survey Frequency Index) observado en el Orden Ephemeroptera.

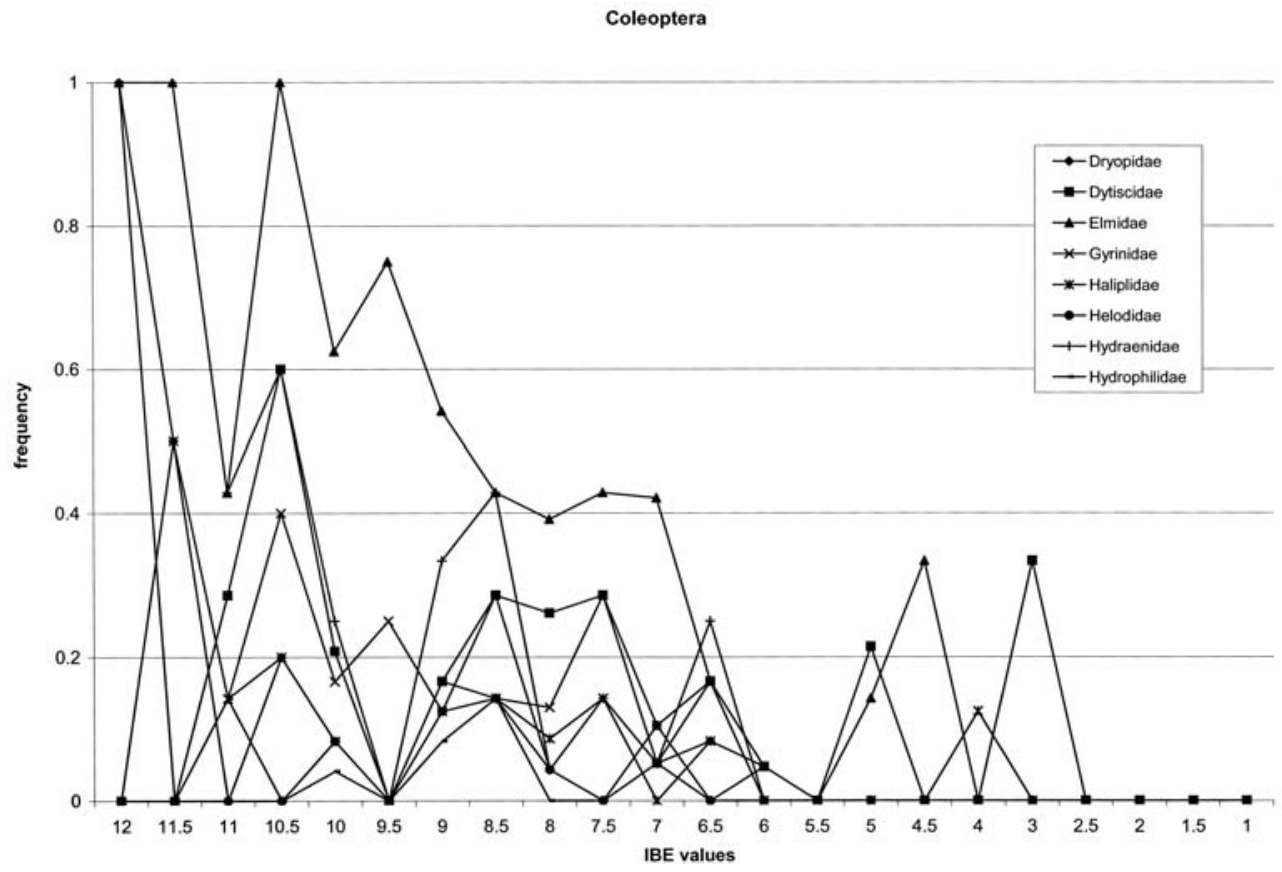

Figure 5: Diagrams of the SFI (Survey Frequency Index) observed in the Order Coleoptera. Diagramas del SFI (Survey Frequency Index) observado en el Orden Coleoptera. 


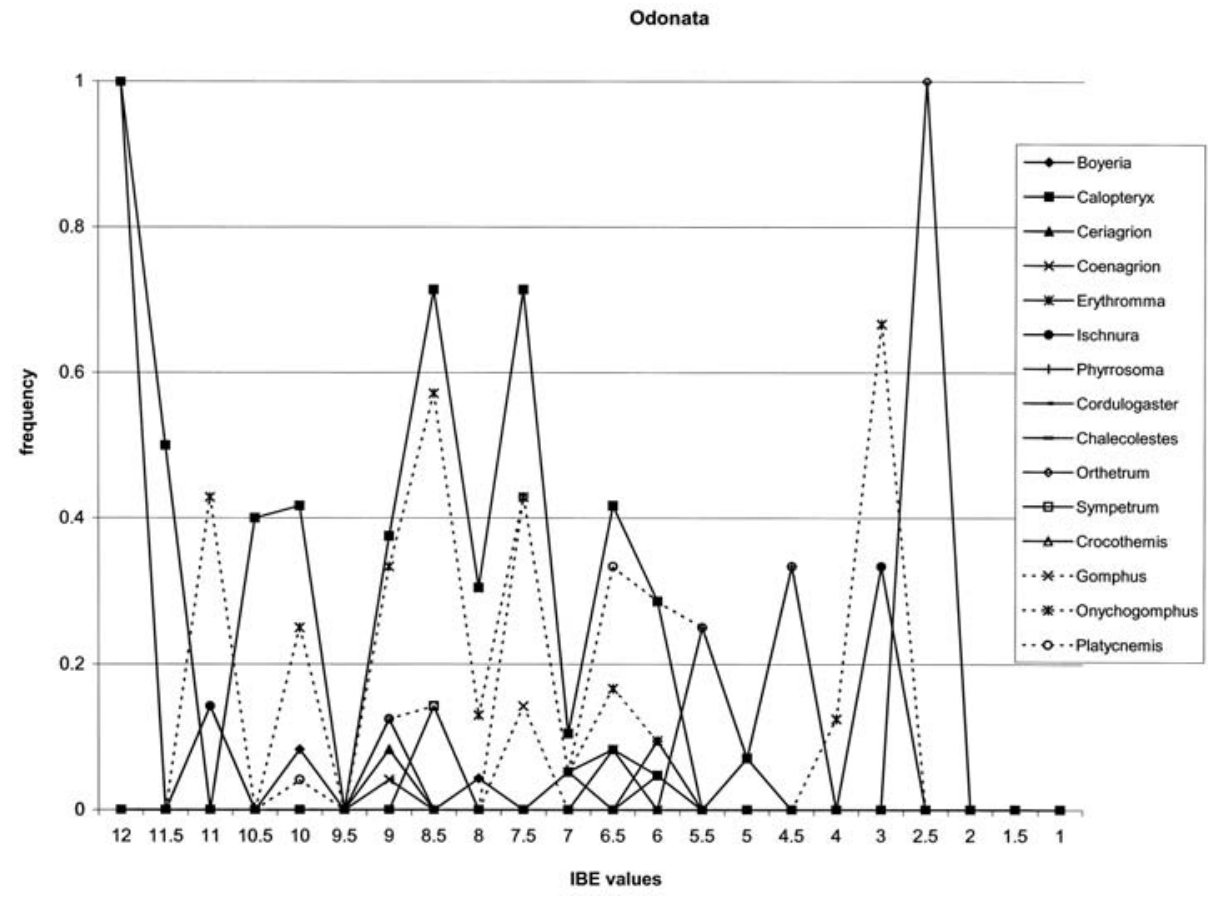

Figure 6: Diagrams of the SFI (Survey Frequency Index) observed within the Order of Odonata. Diagramas del SFI (Survey Frequency Index) observado en el Orden Odonata.

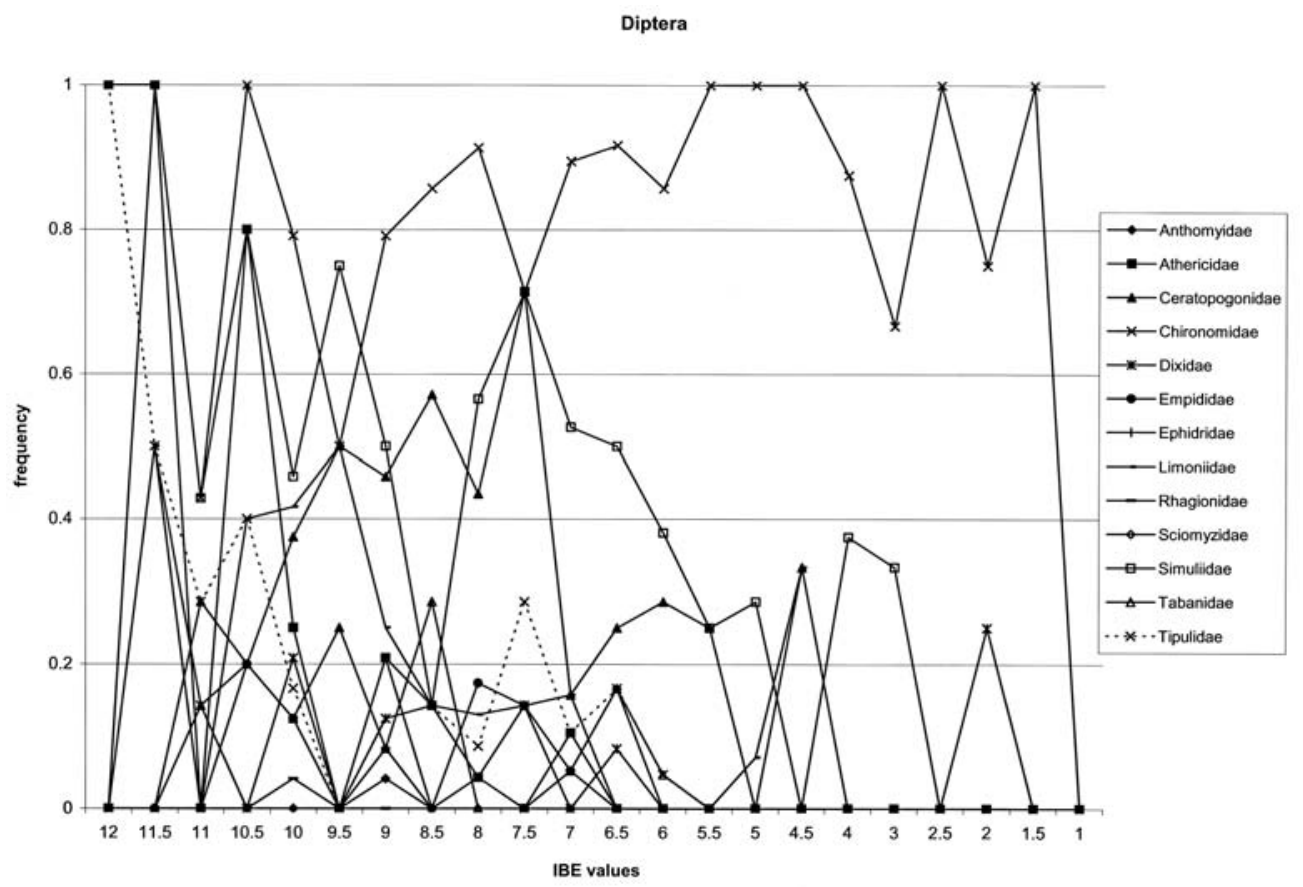

Figure 7: Diagrams of the SFI (Survey Frequency Index) observed within the Order of Diptera. Diagramas del SFI (Survey Frequency Index) observado en el Orden Diptera. 
the investigated taxa. The S.F.I. values clearly put in evidence a higher adaptability and ubiquity of some S.U. compared to their expected intrinsic resistance to pollutants. Otherwise other taxa formerly estimated as "pollution indicators" have evidenced a better fitness exclusively in unpolluted river habitat.

This paper underlines the importance of data about the autoecology of single indicative taxa. These data are essential for a critical approach on the composition of the reference communities and the identification of ecotypes as well as those identified by the European Water Framework Directive (European Union, 2000).

\section{ACKNOWLEDGMENTS}

We are very grateful to all the collaborators for their kind help in the edition of the Biological Quality Map of the Latium Region database, on which this paper is based.

\section{REFERENCES}

ALBA-TERCEDOR, J., C. ZAMORA-MUNOZ \& J. PICAZO-MUNOZ. 1995. Relationship between the distribution of mayfly nymphs and water quality in the Guadalquivir River basin (Southern Spain). In: Current research on Ephemeroptera. L.D. Cockrum \& J.J.H. Ciborowski (eds): 41-54. Canadian Scholar Press Toronto.

BOON, P. J., B. R. DAVIES \& G. E. PETTS. 2000. Global perspectives on river conservation. John Wiley and Sons, Ltd., New York. 548 pp.

EUROPEAN UNION. 2000. Directive 2000/60/EC of the European Parliament and of the Council of 23 October 2000 establishing a framework for Community action in the field of water policy. Official Journal of the European Communities L327, $73 \mathrm{pp}$.

GHETTI, P. F. 1986. I macroinvertebrati nell'analisi di qualità dei corsi d'acqua. Manuale di applicazione - Indice Biotico E.B.I. modificato [Macroinvertebrates in water courses quality analysis. Application Manual, in Italian]. Provincia Autonoma di Trento, Servizio Protezione Ambiente.
GHETTI, P. F. 1997. Manuale di Applicazione: Indice Biotico Esteso - I macroinvertebrati nel controllo della qualità degli ambienti di acque correnti. [Application Manual: Extended Biotic Index Macroinvertebates in quality control of running water environments, in Italian]. Provincia Autonoma di Trento, Servizio Protezione Ambiente.

HELLAWELL, J. M. 1978. Biological Surveillance of rivers. Water Research Centre, Stevenage, England.

ITALY. 1999. Legislative Decree n. 152 of May $11^{\text {th }}$, 1999. «Disposizioni sulla tutela delle acque dall'inquinamento e recepimento della direttiva 91/271/CEE concernente il trattamento delle acque reflue urbane e della direttiva 91/676/CEE relativa alla protezione delle acque dall'inquinamento provocato fai nitrati provenienti da fonti agricole». Official Gazette n. 124, May 29th, 1999, Supplemento Ordinario n. 101/L.

ITALY. 2000. «Ripubblicazione del testo del Decreto legislativo 11 maggio 1999 n. 152. Disposizioni sul Decreto legislativo 18 agosto 2000 n. 248. Disposizioni correttive e integrative del decreto legislativo 11 maggio 1999 n. 152, in materia di tutela delle acque dall'inquinamento a norma dell'articolo 1, comma 4, della legge 24 aprile 1998, n. 128». Official Gazette n. 218 of September $18^{\text {th }}, 2000$, Supplemento Ordinario.

KARR, J. R. 1994. Landscapes and management for ecological integrity. In: Biodiversity and Landscapes: A Paradox of Humanity. K.C. Kim \& R.D. Weaver (eds.): 229-251. Cambridge University Press, Cambridge.

KARR, J. R. 1997. The future is now: Biological monitoring to ensue healthy waters. Northwest Science, 71 (3): 254-257.

KARR, J. R. 1999. Defining and measuring river health. Fresh. Biol., 41: 221-234.

MANCINI, L. \& G. ARCÀ. (eds.). 2001. Carta della qualità biologica dei corsi d'acqua della Regione Lazio [Map of Biological Quality of Latium Region Watercourses, in Italian]. ISS - National Health Institute - \& Latium Region, Rome: 156 pp.

MOSTERT, E. 1998. River basin management in the European Union. How is it done and how should it be done. European Water Management, 3 (1): 26-35.

TITTIZER, T. G. 1976. Comparative study of biological-ecological water assessment methods. In: Comparisons of biological-ecological procedures for assessment of water quality. Amavis, R. \& Smeets, I. (eds.). Practical demonstration of the River Main (2-6 June, 1975). Summary Report. 
VOGT, K. A., J. C. GORDON, J. P. WARGO, D. J. VOGT, H. ASBJORSEN, P. A. PALMIOTTO, H. J. CLARK, J. L. O'HARA, W. S. KEETON, T. PATEL-WEYNAND \& E. WITTEN. 1997. Ecosystems. Balancing Science with Management. Springer-Verlag, New York, 470 pp.

WOODWISS, F. S. 1964. The biological system of stream classification used by the Trent River Board. Chemistry and Industry, 14: 443-447.

WOODWISS, F. S. 1978. Comparative study of biological-ecological water quality assessment methods. Second practical demonstration. Summary Report. Commission of the European Communities.
WOODWISS, F. S. 1980. Biological monitoring of surface water quality. Summary Report. Commission of the European Communities. ENV/787/80-EN.

WRIGHT, J. F., D. MOSS, P. D. ARMITAGE \& M. T. FURSE. 1984. A preliminary classification of running water sites in Great Britain based on macro-invertebrate species and the prediction of community type using environmental data. Freshwater Biology, 14: 221-256.

WRIGHT, J. F., P. D. ARMITAGE, M. T. FURSE \& B. MOSS. 1989. Prediction of invertebrate communities using stream measurements. Regulated Rivers: Research and Management, 4: 147-155. 